\title{
Zanzibar (Tanzania) and the Politics of Foreign Aid. A Case of Impact of Foreign Aid on Development of Health Sector
}

\author{
Suleiman Haji Suleiman. \\ School of Political Science and Public Administration, Shandong University. Jinan City Shandong 27 Shanda \\ Nanlu. Jinan. Shandong Province. P.R. China
}

\begin{abstract}
Foreign aid emerged as a new phenomenon in the field of International Relation after the end of the Second World War. After more than 60 years, it has become one of the most important issues for the international community in Africa, nearly all countries, including Zanzibar, have a connection to foreign aid in one way or another. Most of them receive aids from western countries (USA in particular) and China.As one of the small islands in Indian Ocean, Zanzibar, with population of 1.2 million people, has seen the rises of foreign aid from United States and China in recent years in different economics aspects including Infrastructures, ICT, Education and Health. The general objectives of the article intend to explore the motives behind both donors' aids to Zanzibar. Specifically, compare the roles of China and USA in areas related to health and remark on each donor's relations with Zanzibar.
\end{abstract}

Keywords: Foreign Aid; China/USA Aid.

DOI: 10.7176/PPAR/9-2-02

\section{Introduction}

The cross boarder needs for aid especially in developing countries has been cited to be one of the engines of bringing about development and poverty reduction in Sub-Saharan Africa although empirical information to support this contention is currently inadequate (Kaplinsky 2006). This study therefore aims at assessing the motives behind the Chinese and United States of America's foreign aid towards healthcare in Zanzibar and also the study lies in the need to have in place sufficient empirical information so as to help the relevant authorities when accepting foreign aid for the benefit of the people so that instead of foreign aid becoming a corrupting tool it is used as a tool to bring about self-sustaining development.

Developing countries face massive poverty, slow GDP growth, high mortality rates, and low levels of education. In the year 1999, 1.2 billion people lived on less than \$1 (in PPP US\$) a day, and another 2.8 billion people lived on less than $\$ 2$ a day (World Bank, 2003). The majority of the people in the least developed countries cannot read or write. Over 854 million adults in this world are illiterate, and 543 million of them are women (Human Development Report, 2000). Similarly, many people in developing countries do not have access to health treatment. According to the United Nations Children's Fund (UNICEF), more than 10 million children under five years of age die each year from preventable diseases in these countries for instance by the end of the year 2000, 34 million people were living with HIV/AIDS which is a major concern for all developing countries (Human Development Report, 1998). These statistics reflect the extent of low human development in poor countries.

USAID's Capacity project (2007) Zanzibar's population of nearly one million needs better access to quality health care. Preventable, communicable diseases including malaria and tuberculosis are widespread, and health facilities suffer from a crippling shortage of doctors, nurses and supplies. The principle challenges facing the health system are the HIV/AIDs catastrophe, human resources insufficiency and de-motivation and insufficient funds to meet the growing burden of disease. In Zanzibar resource constraints in health (human and financial) are significant (Capacity project, 2007).

According to Moon (2013), Zanzibar as a semi-autonomous region of Tanzania, consisting of an archipelago of islands off the coast of mainland Africa, inhabit two of the largest islands, Unguja and Pemba, where the combined doctor-to-patient ratio is around 1:20000 (as compared to 1:360 in the UK). Healthcare provision is designed as a three-tiered structure of primary, secondary and tertiary care. Primary care is provided by 134 basic Primary Healthcare Units (PHCUs), which are distributed evenly around the two main islands to ensure that all the population, have a center within five kilometers. On Unguja, secondary care is provided by two hospitals: Makunduchi and Kivunge. Tertiary care is provided by the largest hospital on the archipelago, Mnazi Mmoja, located in the capital Stone Town. In practice, prior to 2006, the hospitals were so dysfunctional that the secondary care tier was provided almost exclusively by Mnazi Mmoja. This led to overcrowding, inadequate staffing, and long patient journeys (Moon, 2013).

As part of the United Republic of Tanzania, Zanzibar maintains its own government and an independent Ministry of Health and Social Welfare. To improve the quality of health care, the Ministry created a Human Resources for Health 5-Year Development Plan. 


\section{THE MOTIVES BEHIND CHINESE AND USA FOREIGN AID TO ZANZIBAR}

Before looking on the motives behind those aid received from donors, it is a good idea to look on US and China aid areas and foreign aid policy as two nations have different approach towards their foreign aid policy. As foreign aid basically refers to the stance and strategies adopted by a state with the intention of promoting its national interests. Foreign aid began as an instrument of Cold War Diplomacy. Without Cold War aid would not exist today, Unlike USA conditional health aid to Africa, Chinese health aid to Zanzibar is based on mutual cooperation; Zanzibar and China cooperate as equal partners with no conditions attached to Chinese foreign aid. During Zanzibar's political standoffs, the United States threatens and sometime withholds their aid. For instance, after the 2000 election and late 2015 election dilemmas, the US threatened to withhold their budgetary support.

During the aftermath of re-election on March 20, 2016 in Zanzibar which saw the main opposition Political Party the Civic United Front (CUF) boycotted together with 5 others Political Parties out of 7 participated on the election, The United States decided to cancel the Millennium Challenge Corporation (MCC) fund of $\$ 472 \mathrm{~m}$ to Tanzania and Zanzibar. MCC issued statement through its Board of Directors on March 28, 2016, explain their decision to cancel the aid due to lack of democracy and freedom of expression in Tanzania and Zanzibar. MCC statement criticizes Tanzania on its decision to move forward with a new election in Zanzibar on March 20, 2016 that was neither inclusive nor representative, despite the repeated concerns of the U.S. Government and the International Community.

MCC criticized The Government of Tanzania for not taken measures to ensure freedom of expression and association in the implementation of the Cybercrimes Act. MCC's model has a partner country's commitment to democracy and free and fair elections at its core. The elections in Zanzibar and application of the Cybercrimes Act run counter to this commitment. As a result, while the United States and Tanzania continue to share many priorities, the MCC Board of Directors determined that the Government of Tanzania has engaged in a pattern of actions inconsistent with MCC's eligibility criteria, and voted to suspend the agency's partnership with the Government of Tanzania and Government of Zanzibar. MCC will therefore cease all activities related to the development of a second compact with Tanzania and Zanzibar.

In fact, USA has gone ahead criticizing Chinese less concern on democracy and human rights. China was the first country to Congratulates the new Government elected of Zanzibar through a cable message sent by Chinese Vice President H.E. Li Yuanchao to the newly appointed President of Zanzibar H.E Dr Ali Mohammed Shein (Zanzibar Leo State Newspaper 2016) and assuring him the support and more cooperation between the two countries to continue for the benefit of their people.

Contrary, China has always insisted on non-interference in domestic matters when providing aid. In this regard China-Zanzibar relationship has continued to flourish despite Zanzibar domestic issues.

This is partly explained by the fact that China and Zanzibar share similar historical background. Both went through colonialism, they cooperated in the fight against imperialism and socialism development. In 2010 the Chinese government donated medical equipment worth 64 million TZS to Zanzibar government. The equipments were handed over by Zhu Xiangjun, Head of Chinese Medical Team in Zanzibar, in his remark, Zhu said the donation was further indication to boost Historical cooperation between Zanzibar and China.

In fact, China regards itself as a developing nation and therefore Zanzibar has got much to learn from China's economic development. Unlike United States who provides aid and tells Zanzibar what to do economically, politically and socially for the aid to be effective. China would provide Zanzibar with foreign aid and let Zanzibar implement the projects in a hand off approach.

Freeman and Boynton (2011) comparing the effectiveness of aids between China and United States concluded that; While China's aid to Africa is not different to that from the West and Multilateral agencies. Chinese aid is effective because it treats recipient countries as equal partners.

\section{Motives behind United States Foreign Aid to Zanzibar.}

Security: According to Maurits van der Veen (2011), one of the primaries aims of the US foreign aid policy is to "increase [US] physical security: support allies, oppose communism, terrorism". History of American aid to Zanzibar supports this argument. After the Zanzibar revolution and in the cold war context the US cut its aid to Zanzibar due to the fact that United States considered Zanzibar's socialist government, its security threat.

However, three decades after the collapse of communism, US foreign aid policy toward Zanzibar has remained in the pursuit of American security goals. In this respect the Millennium Challenge Cooperation was also launched to pursue US core interests, mainly security ones. According to President George W. Bush, in a speech that announced the creation of the Millennium Challenge Corporation during the UN International Conference on Financing the Development:

"We are pursuing great and worthy goals to make the world safer, and as we do, we make it better. We will challenge the poverty and hopelessness and lack of education and failed governments that too often allow conditions that terrorists can seize and try to turn to their advantage". (BUSH, 2002)

Bush meant that neither the US nor International Development can take root without security; it is also true that security does not exist where human beings do not have access to enough food, or clean water, or the 
medicine and shelter they need to survive.

To Zanzibar in particular one can argue that American aid initiatives help to curb Islamic extremism and terrorist influence.

Power/influence: The United States employ foreign aid policy to pursue power increases leverage over others; win allies and positions of influence in international forum (Veen, 2011). The most recent motive of USA aid toward Africa and Zanzibar specifically has been containment of Chinese influence and maintenance of American sphere of influence; retaining American leadership in international development. From the beginning of twenty first Century US reformed its aid agencies and increased its commitment to the development of multilateral organizations in order to effectively consolidated United States power in international arena

Obama once said "We are rebuilding the United States Agency for International Development as the world's premier development agency. In short, we're making sure that the United States a global leader in international development in the 21 st century."

Commercial Interests: Foreign assistance has long been defended as a way to either promote U.S. exports by creating new customers for U.S. products or by improving the global economic environment in which U.S. companies compete (Tarnoff and Lawson, 2011). In Zanzibar, there are overwhelming evidences of USAID awarding many tenders/projects to American firms.

America employs foreign aid policy to promote its export industries. In fact, eight percent of the US foreign aid spent by the US. Employing consultancy services and paying salaries to multilateral organizations staffs. USA also provides digital health assistance to promote domestic medical innovations.

Promote Democracy in Zanzibar: USA foreign aid policy toward Zanzibar is a diplomatic instrument for promoting democratic institutions, the rule of law and supporting civil society. In the early 1990's US employed foreign aid policy to force Zanzibar and African in general, adopt multiparty democracy. Since then US has been emphasizing on the need of Zanzibar to adhere to principles of good governance as criterion for qualification of Millennium Challenge Cooperation.

However, good governance stands to be the toughest criterion to the Zanzibar Revolutionary Government. Elections in Zanzibar are often marred by conflicts between the ruling party and oppositions and sometime resulting into violence. For instance, in 2015-2016 the US denied Tanzania Millennium Challenge grant of about 482 million USD which intended to support energy infrastructure development, citing the ruling party's plot to nullify 2015 general election result (undermining democracy) and Cyber security act of 2015 (human rights concern).

Humanitarianism: Aiding for humanitarian reasons has generally been the least contested purpose of aid by the American public and policymakers alike Mateo (2014). Zanzibar is one of the least developed countries in the world thus USA foreign aid serves basic humanity needs including access to basic education, poverty reduction, feeding children and improvement of fragile healthcare systems.

For example; in 2013 the US celebrated significant reductions in malaria morbidity and mortality in mainland Tanzania and Zanzibar, which have resulted in the protection of up to 8.5 million people annually. This progress was made possible in large part by the Tanzania Vector Control Scale-up Project, implemented by RTI International with support from USAID through the U.S. President's Malaria Initiative (PMI).

\section{Motives behind Chinese Aid to Zanzibar.}

According to China's White Paper on Africa Policy (2010). Beijing's aid model focuses on broader economic cooperation and mutual benefit, and it proudly carries a "no-strings-attached" policy for projects and concessional loans.

Chinese foreign aid allows knowledge and technology transfer, while the USA's aid is mostly based in funding projects. From the beginning China insisted on technology cooperation and knowledge transfer to enable local medical staffs perform sophisticated CMT's roles. In 1965 when Chinese premier visited Zanzibar insisted: CMTs should not only cure the disease, but also help training work. They should bring medicine and facilities, train African doctors, who can be self-reliant, and would work even if the CMT went away". "We would provide sincere help to any independent country. Our assistance is to make the country able to stand up. Since then China has been involved in training Zanzibar's medical staffs through various scholarships, seminars and short trainings. It is an approach that has never been popular in the West particular the United States. In fact, the United States is well known for its expensive patent rights and rarely encourages technological transfer with Africa

Chinese foreign health aid is considered to be a cheaper development assistance compared to United States Health's aid. China is known for its cheaper medicine, medical equipment and services affordable to Zanzibar. In fact, Chinese foreign aid includes concessional loans tied with "procure from Chinese" condition. But for recipient countries (Developing countries) still find the condition more persuading, compared to USA and Western, which have expensive medication, and services tied with political conditionality. As far as the public health is concerned China has the low-cost technology for building water and sanitation systems.

USA relies on both international and local NGO's to implement its projects. USA disburses its fund to 
multilateral agencies such as USAID, Bill, Melinda Gates Foundation and local NGO's to implement key American prioritized health projects. While China aid to Zanzibar is of bilateral terms between the two Governments mainly through the Chinese Institutions such as Ministry of Finance and Commerce MOFCOM, Ministry of Health or Chinese Provinces. For instance, during Chinese President Xi Jinping's visit to Tanzania in 2013, China and Tanzania signed a bilateral agreement on economic and technical cooperation between China and Zanzibar including the rehabilitation and upgrading of China-aided Abdulla Mzee Hospital.

Though critics are suspicious of transparency of bilateral Chinese foreign aid, US's multilateral approach is no short of weaknesses. It has been discovered that almost $8 \%$ of foreign aid is spent in the USAs by suppliers, consultancy companies and multilateral staffs. Therefore, bilateral aid is effective way aiding abroad especially strong ethical government overseeing the aid.

\section{THE LEGACY AND REPUTATION FOR BOTH USA AND CHINA'S AID}

The legacy of confidence and reputation for both USA and China Aid to Zanzibar have increasingly the rapidly for the last 10 years of active involvement.

During the interview with the Former Zanzibar Minister for Health and Social Welfare Hon. Mahmoud Thabit Kombo (Jan 2016) indicated a considerable respect for what China, itself a developing country has achieved the confidence and reputation from Zanzibar Government and its people for their help on improving the development of heath and other sectors Zanzibar through foreign aid which mostly goes directly to the ordinary people.

Many people appreciate highly the service delivery to Chinese Medical Team for the last 50 years in Zanzibar together with assistance of building a newly hospital in Pemba. However, the United States also have managed to control the Malaria death from $40 \%$ in 1995 to $0.1 \%$ in 2012 which people of Zanzibar will never forget when lots of lives were lost due to suffering from malaria. Now Zanzibar is free from malaria and people thanks United States for its efforts to curb and reduce Malaria death by $0.1 \%$. These are big achievements on improving the lives of millions of children and women in Zanzibar. The main differ aspect of confidence and reputation between USA and China health aid are China has managed to win more popularity among people of Zanzibar than USA because China are bilateral Aid country deals more deeper to its aid recipient than USA which works under third party.

\section{Conclusion}

In general, the motives behind the Chinese and United States foreign aid to Zanzibar are to improve their soft diplomacy approach towards aid to Zanzibar people. As evaluated and described above, Many Zanzibar people's perception rated highly to China and USA as the most nations in the world to provided more aid support (economic and social) to Zanzibar in the sectors such as Health, Education, Water projects and Infrastructure, USA concentrated more on malaria and family planning, which they managed to reduce the death rate from $40 \%$ 1995 to $0.1 \%$ 2012. This is a very big achievement on saving people's life. The US aid assistance were supervised by US based Non-Governmental Organizations (NGO).

In 1965 when the Zanzibar Government instructed United States to close down their Tracking Satellite Station in Zanzibar, The US Government in retaliation of that decision has decided to break Diplomatic ties with Zanzibar and stop all Aid including humanitarian Aid to the people of Zanzibar until mid 2000 when they decided to show up again and assisting Zanzibar with several health programs including Malaria Free Initiatives Program, Family Planning and Human Right Education. These US projects were giving out to Zanzibar with conditions including introducing new laws of free press, human rights, civil education through Local Community Radio and Television and transparent Democracy including Independent Electoral Commission.

Chinese Aid to Zanzibar has been enjoyed throughout since 1965 when Zanzibar got independence, never stopped even during the Cultural Revolution where China decided to reduce some of its foreign aid to outside world. Zanzibar has been receiving 22 members of medical team from China every 2 years since then together with medical equipment, medicine, knowledge and technology.

Since this friendship started, China has built new referral hospitals in Zanzibar with new State of Art Operating Theatre. The Medical Team provide services direct to the people of Zanzibar in Hospitals Urban and Rural areas, most of the families in Zanzibar have been treated by Chinese Doctors and have experience on life saving stories when they were serious sick.

Nevertheless, Chinese and United States foreign aid to Zanzibar have been playing active role for development of Zanzibar. Zanzibar has been enjoying assistance for health sector for many years but still a lot need to be done to improve the health sector. The Government needs to establish better quality hospitals in the rural areas with good doctors together with full equipment, so the people can be served there and avoiding overcrowding in the main referral hospitals.

In Conclusion, China has played an important role in proving assistance to the people of Zanzibar, many people in Zanzibar shows their gratitude and appreciation to China than USA. These based on one to one contact 
between Chinese Medical Teams and local people (Patients) in Hospitals. Between 2005 to 2015 China has managed to treat about 722,430 patients on clinical based, number of Inpatient are 93,744 patients and about performed about 34,080 life saving Operations for patients in Zanzibar for the last 10 years (Zanzibar Ministry of Health of Health 2016).

No family in Zanzibar never comes across or contact with medical help from Chinese Doctors when they need medical attention in the 50 years their hard working in Zanzibar. Even Government of Zanzibar's perceptions towards China foreign aid to Zanzibar are too high compared with United States and other donors Countries. The confidence and reputation to Chinese Aid seems, as they are more humanitarian and shows as a sign of good friendship between China and Zanzibar due to its Unconditional with condition aid from USA. According to the Zanzibar Minister of Health (2016) during the interview mentioned that the Government and people of Zanzibar, feels like China is more a good friend of Zanzibar and has provided foreign aid since 1965 up to now without ceasing or decrease their aid, while USA abandoned Zanzibar in 1965 and decided to reduces its aid to Zanzibar for nearly 25 years due to confrontation caused by cold war era in 1960's.

In order to win the heart of people in Zanzibar and other aid recipients, USA must find a new approach or review its foreign aid policy strategies towards Zanzibar, the biggest challenges face US in today's world which caused its aid non-attracted to many is the way they apply its foreign policy which allows them to make interference in the economic and political activities the recipient country.

As China do, The USA should change the way to manage well its foreign aid through International Agencies and follow what China do on providing its foreign aid, by dealing directly between Government to Government and not through third party like USAID. These may help to impose reputation and good images to the majority of people in the recipient countries.

\section{References}

China's Foreign Aid, (2011), Information Office of the State Council, People's Republic of China. Beijing.

Freeman and Boynton (2011). "China emerging Global Health". Washington DC, Center for Strategic and International Studies, Washington Dc.

Hon Mahmoud Kombo (2016). Minister for Health. Report on Development of Health Sector in Zanzibar for 2011-2016.

Kaplinsky, R.D. (2006), "Impact of China on Sub-Saharan Africa”, Paper Commissioned by DFID Office in China.

Moon S, Omole O. Development assistance for health: Critiques and proposals for change. Centre on Global Health Security Working Group Papers. London: Chatham

House, 2013.

Mateo (2014) "Foreign aid and U.S. international strategy formulation after the 9/11" Sao Paulo University

Tarnoff and Lawson (2011) "Foreign Aid: An Introduction to U.S. Programs and Policy”. Washington, Congress Research Services.

United Nations Development Program (1998), Human Development Report. United Nations, New York, NY. United Nations Development Program (2000), Human Development Report. United Nations, New York, NY USAID: US Development Aid (2007): A Historic First Achievements and Failures in the Twenty Century. VEEN, A. (2011) Ideas, interests and foreign Aid. New York: Cambridge University Press.

I was born in Zanzibar Tanzania 1974 as first child to a young mother who just graduated her medical degree in the Soviet Union. I completed my First Degree in the London United Kingdom in 2000 and Master of Law in International Relations at Jilin University in Changchun China before joined for my Doctorate Degree at Shandong University in Jinan Shandong Province.

Highly experience in Marketing and Administration with enough experience on Government issues. For the last 10 years I worked as D/Private Secretary to the Chief Minister of Zanzibar Tanzania and then Vice President of Zanzibar Tanzania.

Currently, I am using much of my time teaching Undergraduate Students in Universities in China in the areas of International relations, Law and Business Management. 